\title{
PENGEMBANGAN KAPASITAS USAHA MELALUI PENGELOLAAN PROSES PRODUKSI DAN PEMASARAN UNTUK MENINGKATKAN PENDAPATAN PETANI KOPI DI DESA MARIA UTARA KABUPATEN BIMA
}

\author{
Syafruddin ${ }^{1}$, Nurseha ${ }^{2}$, Rabiatul Adwiyah ${ }^{3}$, Nur Ismawati ${ }^{4}$, Dita Faradillah ${ }^{4}$, Ainun Jariah ${ }^{4}$, \\ Herawati $^{4}$, Fatayatun Nurarifiati ${ }^{4}$, Nurfaujiah ${ }^{4}$, Ratu Karmila ${ }^{4}$ \\ ${ }^{1}$ Program Studi Pendidikan Sosiologi, Universitas Mataram, Mataram, Indonesia. \\ ${ }^{2}$ Program Studi Pendidikan Biologi, Universitas Mataram, Mataram, Indonesia. \\ ${ }^{3}$ Program Studi Pendidikan Anak Usia Dini, Universitas Mataram, Mataram, Indonesia. \\ ${ }^{4}$ Program Studi Pendidikan Guru Sekolah Dasar, Universitas Mataram, Mataram, Indonesia. \\ * Coressponding Author. E-mail: syafruddin fkip@unram.ac.id
}

\section{Received: 4 Februari $2022 \quad$ Accepted: 4 Februari 2022 Published: 6 Februari 2022}

\begin{abstract}
Abstrak
Kuliah Kerja Nyata (KKN) Terpadu Desa Preneur merupakan sebuah kegiatan pengabdian kepada masyarakat yang melibatkan mahasiswa sebagai peserta dan dosen sebagai pembimbing yang berfokus pada tema desa preneur. Desa Maria Utara mempunyai potensi alam ysng melimpah, diantaranya : kopi, kemiri, madu, kunyit, jahe merah dan mete. Kelompok Kuliah Kerja Nyata (KKN) Terpadu Universitas Mataram periode 2021/2022 mengambil "Sumber Daya Alam Kopi" untuk dikembangkan sebagai bentuk pemberdayaan demi terciptanya kesejahteraan masyarakat. Kegiatan ini bertujuan untuk. Hasil dari rangkaian kegiatan pengabdian ini adalah pengembangan kemasan, pemasaran dan membuat produk baru olahan kopi.
\end{abstract}

Kata Kunci: KKN Terpadu, Desa Maria Utara, Kopi

\section{PENDAHULUAN}

Desa Maria Utara adalah salah satu dari sembilan desa yang berada di kecamatan Wawo Kabupaten Bima yang memiliki lokasi yang berada pada ketinggian 387 MDPL. Desa Maria Utara mempunyai potensi alam yang melipah, diantaranya : kopi, kemiri, madu, kunyit, jahe merah dan mete. Sumber daya alam yang ada di Desa Maria Utara dengan hasil alam yang melimpah, tidak heran jika Desa Maria Utara menjadi salah satu desa dengan penghasilan yang tinggi setiap tahunnya di Kecamatan Wawo. Mayoritas penduduknya adalah petani, sehingga jika ada lahan kosong selalu dikelola untuk bertani.

Tema Kuliah Kerja Nyata (KKN) adalah Desa Preneur. Kelompok Kuliah Kerja Nyata (KKN) Terpadu Universitas mataram periode 2021/2022 mengambil "Sumber Daya Alam Kopi" untuk dijadikan program kerja utama selama 45 hari kegiatan KKN. Hasil wawancara yang dilakukan dengan kepala desa berkaitan dengan sumber daya alam yaitu kopi menjadi hal menarik untuk diteliti dan dikembangkan.
Hal ini disebabkan karena kopi memiliki permintaan paling banyak di pasar. Kopi di Dusun Kawae Desa Maria Utara juga baru selesai dipanen sehingga memudahkan untuk melakukan observasi dan mengembangkan produk baru.

Jenis kopi yang ditanam di Dusun Kawae adalah jenis Kopi Robusta. Kopi Robusta adalah keturunan beberapa spesies kopi terutama coffe canephora. Jenis kopi ini tumbuh baik di ketinggian 400-700 mdpl, temperatur $21-24^{\circ} \mathrm{C}$ dengan bulan kering 3-4 bulan secara berturut-turut dan 3-4 kali hujan kiriman. Kualitas buah lebih rendah dari arabika dan Liberika. Bentuk biji lebih bulat dan belahan yang dimiliki juga cenderung lebih lurus. Kopi Robusta memiliki rasa yang cendrung kuat dan pahit. Rasa pahit itu sebenarnya juga menandakan kadar kafein pada Robusta yang tinggi, yaitu: $1.5 \%-3.3 \%$ atau dua kali lipat kandungan kafein Arabika. Kopi Robusta mampu beradaptasi dengan baik pada kondisi iklim yang hangat.

Sumber daya manusia adalah komponen penting yang berfungsi sebagai penggerak 
Jurnal Pengabdian Inovasi Masyarakat Indonesia, 1 (1), 2022 - 7

Syafruddin, Nurseha, Adwiyah, Ismawati, Faradillah, Jariah, Herawati, Nurarifiati, Nurfaujiah, Karmila

kegiatan produksi dalam sebuah organisasi atau perusahaan. Sumber daya manusia di Desa maria Utara sudah memenuhi standar, namun yang menjadi permasalahan adalah kurangnya pengetahuan, sehingga belum bisa berkembang dengan baik. Dari hasil wawancara yang kami lakukan dengan petani kopi, petani kopi masih mengalami kendala pada penggunaan mesin pengolah kopi, cara perawatan kopi, dan cara pengolahan kopi. Sudah beberapa kali dilakukan sosialisasi oleh pemerintah, namun masyarakat belum bisa menerapkannya dengan baik.

Kopi Robusta di Dusun Kawae di jual dalam bentuk biji yang sudah digiling (dipisahkan dengan kulit) dan dijual dalam bentuk kemasan bubuk. Permintaan pasaran yang semakin meningkat maka produksi kopi juga meningkat yang tentunya mampu meningkatkan ekonomi masyarakat di desa tersebut. Tim KKN terpadu UNRAM akan bekerja sama dengan petani kopi untuk bersama-sama mengembangkan produk olahan kopi dan mempromosikan kopi di pasar internasional.

\section{METODE PELAKSANAAN}

Kegiatan yang dilakukan dalam program KKN Desa Preneur ini adalah membantu masyarakat desa Maria Utara dalam mengembangkan potensi usaha yang ada. Dalam hal ini, pertama-tama kegiatan yang kami lakukan adalah melakukan wawancara kepada aparat desa mengenai demografis, kependudukan dan keadaan lingkungan di Desa Maria Utara.

Observasi yang kami lakukan ini menghasilkan bahwa potensi SDA yang ada di Desa Maria utara ini sangat melimpah ruah seperti rempah-rempah,kopi serta pohon kemiri.

\section{HASIL KEGIATAN}

Dalam jangka waktu kegiatan KKN di Desa Maria Utara Kecamatan Wawo ada beberapa kegiatan Tim KKN yang utama yaitu tetang budidaya kopi. Kegiatan KKN yang utama adalah kegiatan Tim yang berkaitan dengan mencari solusi terhadap kendalakendala yang dihadapi oleh para pengelola usaha industri kopi, yang ini menjadi penghasilan tambahan bagi masyarakat di Desa
Maria Utara sehingga dapat meningkatkan ekonomi masyarakat, sedangkan kegiatan tambahan adalah program kegiatan Tim KKN yang menunjang kemajuan Desa Maria Utara kegiatan tersebut berupa Desain Kemasan Kopi, pembuatan permen dan lilin. Yang bahan dasarnya adalah Kopi.

Dari hasil analisis kegiatan yang telah dilakukan selama 45 Hari pelaksanaan kegiatan KKN sebagian besar program telah selesai dilakukan dengan menghasilkan hal-hal sebagai berikut:

1. Tim KKN bekerja sama dengan petani kopi di Desa Maria Utara lebih tepatnya di Dusun Kawae Kecamatan Wawo.

2. Dari hasil wawancara kelompok Tani yang ada di Desa ada anggota kelompok tani yang belum tau secara jelas berkaitan dengan tatakelola lahan dan penyakit pohon kopi dan cara panen yang baik.

3. Berkaitan dengan harga kopi yang sangat murah, karena dipermainkan oleh pedagang salah satu penyebabnya adalah pada saat panen petani berusahan ingin menjual hasil pohon kopinya. Peluang tersebut ditangkap permodalan untuk pengembangan usaha mereka.

4. Permasalahan yang dihadapi oleh mitra selanjunya adalah peningkatan hasil produksi industri pengolahan kopi yang masih terbatas atau masih minim, akar permasalahannya adalah berkaitan dengan peralatan yang dipakai masih terbatas dan masih menggunakan alat-alat tradisional.

5. Pemasaran merupakan permasalahan yang sering dihadapi oleh seluruh industri kecil dan menengah, Hal tersebut tidak jauh beda dengan industri pengolahan kopi. Tim KKN membantu petani kopi untuk memasarkan dan mempromosikan Kopi di sosial media (facebook, instagram, dan whatsapp).

6. Tim KKN Terpadu UNRAM bekerja sama dengan petani kopi di Dusun Kawae Desa Maria Utara mendesai kemasan produk kopi yang bar agar terlihat lebih menarik. 
Jurnal Pengabdian Inovasi Masyarakat Indonesia, 1 (1), 2022 - 8

Syafruddin, Nurseha, Adwiyah, Ismawati, Faradillah, Jariah, Herawati, Nurarifiati, Nurfaujiah, Karmila

Dokumentasi Kegiatan

1. Diskusi dengan petani kopi

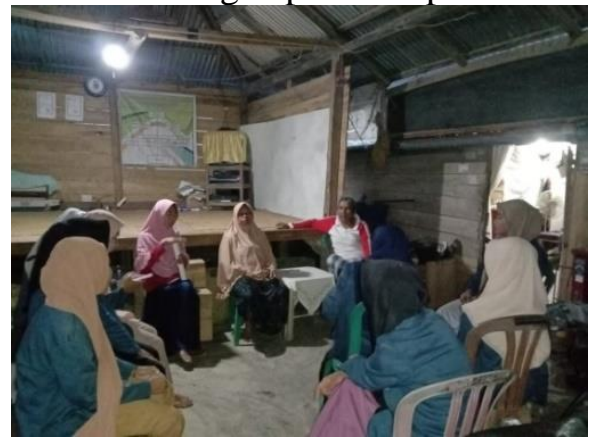

2. Survey lokasi kebun kopi

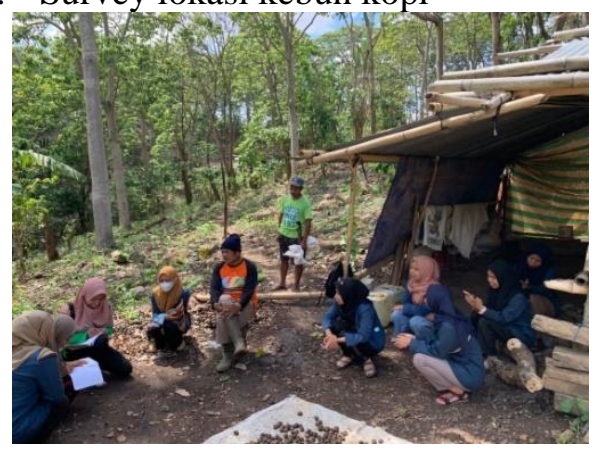

3. Percobaan pembuatan produk

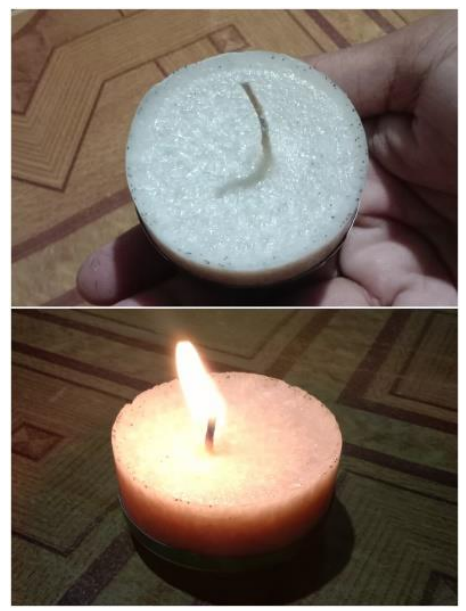

4. Desain kemasan produk

Desain awal

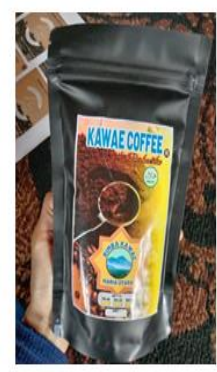

Desain baru

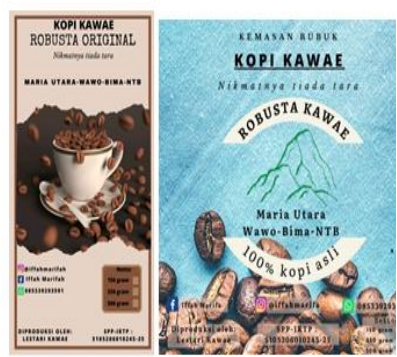

\section{KESIMPULAN DAN SARAN}

Kuliah Keja Nyata dan pengabdian masyarakat (KKN) yang dilaksanakan di Desa Maria Utara Kecamatan Wawo Kabupaten Bima ini, memfokuskan di bidang SDA kopi. Untuk meningkatkan perekonomian masyarakat di Desa Maria Utara.

Pembelajaran dan pengabdian masyarakat (KKN) yang dilakukan selama ini, menggunakan metode praktis sesuai kebutuhan, beberapa masukan yang diberiakan diantarannya: memberikan motifasi usaha, perhitungan harga penjualan, penetapan target penjualan, penetapan harga penjualan.

Dari hasil wawancara yang kami lakukan dengan petani kopi, petani kopi masih mengalami kendala pada penggunaan mesin pengolah kopi, cara perawatan kopi, dan cara pengolahan kopi. Sudah beberapa kali dilakukan sosialisasi oleh pemerintah, namun masyarakat belum bisa menerapkannya dengan baik.

\section{UCAPAN TERIMA KASIH}

Ucapan terima kasih kepada:

1. Prof. Dr. H. Lalu Husni, S.H., M.Hum., Rektor Universitas Mataram.

2. Muhammad Ali, S.Pt., M.Si., Ph.D Ketua Lembaga Penelitian dan Pengabdian Kepada Masyarakat (LPPM) beserta jajarannya.

3. Prof. Dr. A. Wahab Jufri, M. Sc., Dekan FKIP Universitas Mataram.

4. A. Rafik selaku Kepala Desa Maria Utara beserta jajarannya.

5. Petani kopi di Dusun Kawae dan masyarakat yang ada di Desa Maria Utara.

\section{DAFTAR PUSTAKA}

Arifin, Miftah dan Ariyanto. 2018. Desa Penghasil Kopi untuk Meningkatkan Ekonomi Masyarakat di Desa Damarwulan Kecamatan Keling Kabupaten Jepara. Jurnal ABDIMAS Unmer Malang, 3(1), 19-22.

Purwadi, Marsi Adi. 2018. Budidaya Tanaman Kopi Arabika sebagai Pendorong Ekonomi Masyarakat di Kabupaten Intan Jaya. Jurnal Jurusan Manajemen Fakultas Ekonomi dan Bisnin Universitas Cendrawasih, 2(1), 1-2.

Rahayu, Ahadiyat Yugi, dkk. 2019.

Pengembangan Budidaya Kopi Robusta 
Jurnal Pengabdian Inovasi Masyarakat Indonesia, 1 (1), 2022 - 9

Syafruddin, Nurseha, Adwiyah, Ismawati, Faradillah, Jariah, Herawati, Nurarifiati, Nurfaujiah,

Karmila

Organik pada Kelompok Tani Sido

Makmur Desa Pesangkalan Kabupaten

Banjar Negara. Jurnal Ilmiah

Pengabdhi. 5(2), 105-107.
LPPM UNRAM. 2020. Panduan Kuliah Kerja

Nyata (KKN) Era New Normal

Universitas Mataram. Universitas

Mataram: Lembaga Penelitian dan

Pengamdian Kepada Masyarakat. 